\title{
Relationship between Zoometric Measurements in Holstein- Friesian Cow and Cubicle Size in Dairy Farms
}

\author{
Relación entre Medidas Zoométricas en Vacas Holstein-Friesian \\ y Dimensiones de Cubículos en Granjas Lecheras
}

Cerqueira, J. O. L."; Araújo, J. P. P.,"*; Vaz, P. S."; Cantalapiedra, J.**; Blanco-Penedo, I.**** \& Niza-Ribeiro, J. J. R..****

CERQUEIRA, J. O. L.; ARAÚJO, J. P. P.; VAZ, P. S.; CANTALAPIEDRA, J.; BLANCO-PENEDO, I. \& NIZA-RIBEIRO, J. J. R. Relationship between zoometric measurements in Holstein-Friesian cow and cubicle size in dairy farms. Int. J. Morphol., 31(1):5563, 2013.

SUMMARY: Body measurements in Portuguese Holstein-Friesian breed and its association with the dimensions of the cubicles were investigated. During a period of 5 months, body measurements and cubicles size data from 55 commercial Portuguese dairy herds were collected including in total 1054 individual cows. Data were analyzed using the general linear model and principal components. The most relevant body measurements were: height at withers $(141.1 \pm 4.72 \mathrm{~cm})$, height at rump $(144.2 \pm 4.47 \mathrm{~cm})$, length of trunk $(170.8 \pm 8.31$ $\mathrm{cm})$, width of biiliac $(55.9 \pm 4.17 \mathrm{~cm})$ and perimeter of the thorax $(206.8 \pm 10.43 \mathrm{~cm})$. In general, the first class of parity showed significant different measures $(\mathrm{P}<0.001)$ associated with the development of animals. Head to head cubicle length and cubicle width were $223.0 \pm 11.0$ $\mathrm{cm}$ and $113.0 \pm 5.0 \mathrm{~cm}$ respectively; whereas in cubicle against wall length was $227.0 \pm 18.0 \mathrm{~cm}$ and width $111.0 \pm 7.0 \mathrm{~cm}$. The highest correlations were found for body measures between the different heights and between the height at chest and perimeter of the thorax. The analysis showed no relation between body measurements and dimensions of the cubicles. Principal component analysis of the different body measurements and cubicles dimensions expressed $51.4 \%$ of the total variability, in which the first factor represented $40.2 \%$ and the second factor $11.1 \%$.

KEY WORDS: Holstein-Friesian; Measurements; Cubicles.

\section{INTRODUCTION}

The selection of currently practiced, highly values of the body size, as it is directly related to the animal's weight, however the size, which is the weight, the best indicators, affects the costs of production and biological and economical efficiency of the herds. In addition, the size is directly related to the body structure, harmony and balance of the animals, together with other physiological characteristics, act directly on the mechanisms for adaptation to the environment (Peters, 1993).

Most dairies have turned to total confinement freestall housing in an attempt to optimize labor, facilities, land use and to meet the more stringent environmental regulations (Overton et al., 2002) and animal welfare requirements (EFSA, 2012). Cubicle size and design is crucial, particularly as the average size of the dairy cow has increased over the last 40 years and many cubicles installed two or three decades ago are no longer of sufficient size or adequate design to accommodate them comfortably and efficiently. At the very worst, some cows may find these cubicles so uncomfortable that despite being 'cubicletrained', they will choose to lie in dirty passageways and not in the cubicle at all. With the aid of modern genetic tools and based on the economy and the market forces, breeders have managed to increase the productivity of their animals and thus have improved herds that produce more milk. The costs of these successes of progress are charged directly to the same enhanced animals which collaterally are affected in their welfare, survival, reproduction and biodiversity (Camargo, 2012).

Escola Superior Agrária do Instituto Politécnico de Viana do Castelo, Portugal.

** CIMO - Centro de Investigação de Alta Montanha, Bragança, Portugal.

*** Servicio de Ganaderia de Lugo, Xunta de Galicia, Spain.

***** Animal Welfare Subprogram, IRTA, Finca Camps i Armet, Girona, Spain.

******Instituto de Ciências Biomédicas Abel Salazar da Universidade do Porto, Portugal. 
Several terms are used to describe the space afforded to animals during confinement: stocking density or rate, and space allocation or allowance are some of the most popular. Space allowance (or allocation) is just a measure of the area available, and is usually used for one animal's requirement. An animal does not necessarily use all of the space allowance, but it has the potential to do so (Petherick \& Phillips, 2009).

The performance of some behavioural patterns, such as those associated with feeding, drinking, excretion and resting are critical for immediate survival, whilst other behaviours, such as locomotion/exercise, self-grooming and social behavior are only essential for longer-term health and welfare (Petherick, 2007). The North American Holstein cows are larger (Agnew et al., 2003), ingest greater amounts of food and produce more milk (Linnane et al., 2004), but are most infertile, have more diseases and have short longevity (Knaus, 2009).

Whither height, hip height, and hip width are indicators of skeletal development (body size) that are relatively easy to obtain precisely because the anatomical locations for measurement are easy to identify. These measurements can also be made from behind the cow, which is practical in most housing systems. Another advantage is that height and width measurements represent two extremes, which respect to skeletal development. Mature height is developed first (91\% at 21 months of age), and mature hip width is developed last ( $84 \%$ at 21 months of age). Because skeletal development is progressive and relatively slow, few measurements are needed to determine precisely a valid growth curve for the individual animal through interpolation and extrapolation (Enevoldsen \& Kristensen, 1997).

The purpose of this study was to perform biometrical characterization of Holstein-Friesian breed and evaluated the adequacy of cubicles according to the size of the animals.

\section{MATERIAL AND METHOD}

Cows population distribution. The herds in this study represent a median of herd size of 74 with Holstein Friesian as the only breed and an average milk production of 9747 $\mathrm{kg}$ per cow per 305-day lactation.

In Northwest of Portugal, most dairy farms are placed in the free stalls intensive system with cubicles (Araújo et al., 2007). The region under study included four districts that covered a total of 18 municipalities, Aveiro (Águeda, Arouca, Aveiro, Estarreja, Ilhavo, Murtosa, Oliveira de Azemeis, Ovar and Vagos), Braga (Barcelos, Braga and Vila Verde), Porto (Famalicão, Póvoa de Varzim and Vila do Conde) and Viana do Castelo (Paredes de Coura, Ponte de Lima and Viana do Castelo). Fifty-five dairy farms were randomly selected from this area. This region represents a $38 \%$ of the national milk production (FENALAC, 2011).

We considered three classes of animals parities, with reference to inclusion in different classes, the moment of taking the measurements and date of birth of animals: 1 : 1st parity, 2: 2nd or 3rd parity and 3: $\geq 4$ th parity.

Data collection. From May to September 2009, body measurements were collected to characterise the morphological variation in the Holstein-Friesian cattle population, from 1054 adult cows (postpartum), consisting of 403 first parity, 460 second and third set parity and 191 fourth or higher parity. For each animal, body measurements were carried out using a lydthin stick, a tape measure and a vernier calliper. The animals were on an upright plane during the measurements. The exact position of each reference point of measurement was identified on animals by palpation on the relevant anatomical bone. The body measurements included (Fig. 1) height at withers (HW), height at back (HB), height at rump (HR), height at pin bones (HPB), height at chest (HC), length of trunk (LT), length of rump (LR), length of head (LH), width of head (WH), width of chest (WC), width of biiliac (WBIIL), width of biischiatic (WBIIS), perimeter of the shin (PS), and perimeter of the thorax (PT).

Cubicles measurements were collected by direct measurement of the equipment with tape measure, cubicle length (CL) and cubicle width (CW).

Statistical analyses. Data were analyzed using the general linear model (GLM) procedure of the SPSS package version 19 software (SPSS, Chicago, IL, USA). The effect of parity was studied by analysis of variance (ANOVA) procedure. The general model used was:

$$
Y i j=\mu+P i+e i j,
$$

where Yij is the observation of the biometric measure $\mathrm{i}$ for any of the dependent variables; $\mu$ is the overall mean; $\mathrm{Pi}=$ is the effect of parity $i(i=1,2,3)$; eij. is the residual random error associated with the observation ij. The HSD Tukey's test was applied to compare the mean values obtained. Differences between pair-wise combinations of the least square means were tested for significance $(\mathrm{P}<0.05)$. 


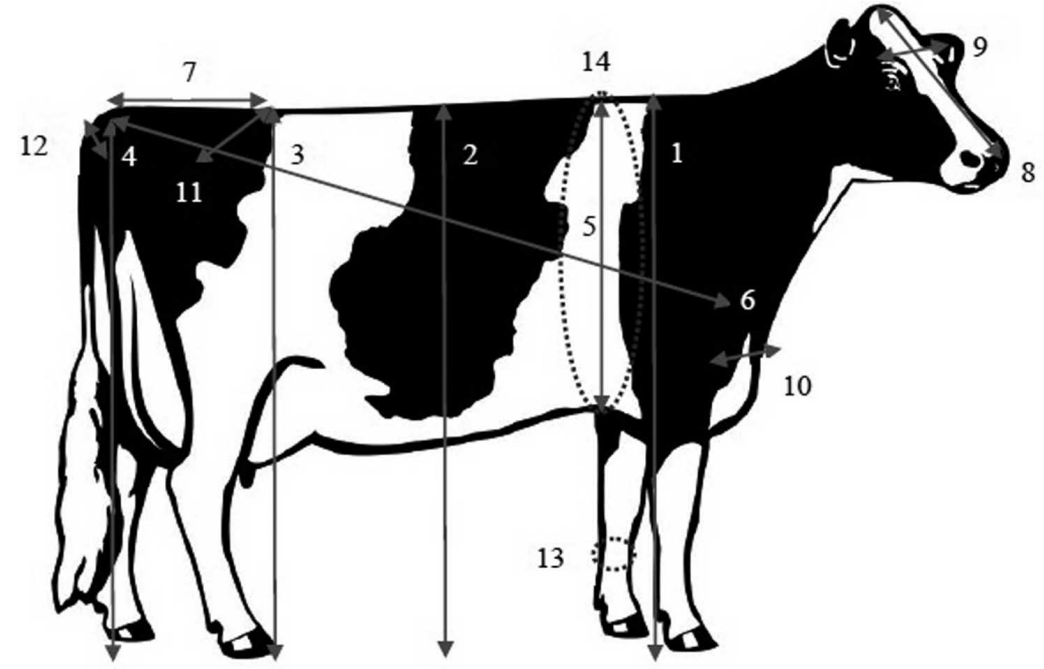

Fig. 1. Indication of biometric measurements performed in animals of our study. 1HW, 2- HB, 3- HR, 4- HPB, 5- HC, 6- LT, 7- LR, 8- LH, 9- WH, 10- WC, 11WBIIL, 12- WBIIS, 13- PS, 14- PT.

\section{RESULTS}

The most important measures were the height at withers, which amounted to $141.1 \pm 4.7 \mathrm{~cm}$ and height at rump, $144.2 \pm 4.5$ $\mathrm{cm}$. In measurements of height class studied for the effect of parity (Table I), significant differences $(\mathrm{P}<0.001)$ were found between animals of first lactation and the other measures at the level of $\mathrm{HW}$ and $\mathrm{HB}$ $(\mathrm{P}<0.001)$ which was not observed for the second and third class of lactation $(\mathrm{P}>0.05)$. For the HR cows in first and fourth or greater lactation showed the similar heights and significantly lower $(\mathrm{P}<0.001)$ for the second class of lactation. In HPB, the first two classes of lactation showed significant differences $(\mathrm{P}<0.001)$, with measures in

Table I. Descriptive statistics of biometric heights according to the parity class.

\begin{tabular}{|c|c|c|c|c|c|c|}
\hline Measure & Parity & $\mathbf{n}$ & Mean \pm SD & Minimum & Maximum & CV $(\%)$ \\
\hline \multirow{5}{*}{ HW } & $1 \mathrm{st}$ & 403 & $138.9^{\mathrm{a} \pm}{ }^{4} .6$ & 124.0 & 154.5 & 3.3 \\
\hline & $2 \mathrm{n}^{\mathrm{d}}$ and $3 \mathrm{r}^{\mathrm{d}}$ & 460 & $142.4^{\mathrm{b}} \pm 4.2$ & 129.5 & 158.0 & 2.9 \\
\hline & $\geq 4 \mathrm{t}^{\mathrm{h}}$ & 191 & $142.7 \mathrm{~b} \pm 4.4$ & 132.0 & 157.0 & 3.1 \\
\hline & Sig. & & $* * *$ & & & \\
\hline & Total & 1054 & $141.1 \pm 4.7$ & 124.0 & 158.0 & 3.3 \\
\hline \multirow{5}{*}{$\mathrm{HB}$} & $1 \mathrm{st}$ & 403 & $140.3^{\mathrm{a} \pm}{ }_{4.7}$ & 123.0 & 154.0 & 3.4 \\
\hline & $2 \mathrm{n}^{\mathrm{d}}$ and $3 \mathrm{r}^{\mathrm{d}}$ & 460 & $143.3 \mathrm{~b} \pm 4.4$ & 129.0 & 160.0 & 3.1 \\
\hline & $\geq 4 \mathrm{t}^{\mathrm{h}}$ & 191 & $143.1 \mathrm{~b} \pm 4.6$ & 131.0 & 155.0 & 3.2 \\
\hline & Sig. & & $* * *$ & & & \\
\hline & Total & 1054 & $142.1 \pm 4.8$ & 123.0 & 160.0 & 3.4 \\
\hline \multirow{5}{*}{ HR } & $1 \mathrm{st}$ & 403 & $143.4^{\mathrm{a} \pm}{ }^{ \pm} .5$ & 125.0 & 156.0 & 3.1 \\
\hline & $2 \mathrm{n}^{\mathrm{d}}$ and $3 \mathrm{r}^{\mathrm{d}}$ & 460 & $145.0^{\mathrm{b}} \pm 4.3$ & 130.0 & 162.0 & 2.9 \\
\hline & $\geq 4 \mathrm{t}^{\mathrm{h}}$ & 191 & $143.5^{\mathrm{a} \pm} 4.5$ & 129.0 & 155.0 & 3.1 \\
\hline & Sig. & & $* * *$ & & & \\
\hline & Total & 1054 & $144.2 \pm 4.5$ & 125.0 & 162.0 & 3.1 \\
\hline \multirow{5}{*}{ НPB } & $1 \mathrm{st}$ & 403 & $139.5^{\mathrm{a} \pm} 4.9$ & 119.5 & 153.0 & 3.5 \\
\hline & $2 \mathrm{n}^{\mathrm{d}}$ and $3 \mathrm{r}^{\mathrm{d}}$ & 460 & $140.2^{\mathrm{a} \pm}{ }_{4.6}$ & 125.0 & 151.0 & 3.3 \\
\hline & $\geq 4 \mathrm{t}^{\mathrm{h}}$ & 191 & $138.5 \mathrm{~b} \pm 4.6$ & 120.5 & 149.0 & 3.3 \\
\hline & Sig. & & $* * *$ & & & \\
\hline & Total & 1054 & $139.6 \pm 4.8$ & 119.5 & 153.0 & 3.4 \\
\hline \multirow{5}{*}{$\mathrm{HC}$} & $1 \mathrm{st}$ & 403 & $74.2 \mathrm{a} \pm 3.3$ & 64.0 & 83.0 & 4.5 \\
\hline & $2 \mathrm{n}^{\mathrm{d}}$ and $3 \mathrm{r}^{\mathrm{d}}$ & 460 & $77.4 \mathrm{~b} \pm 3.0$ & 68.0 & 87.0 & 3.9 \\
\hline & $\geq 4 \mathrm{t}^{\mathrm{h}}$ & 191 & $78.4 \mathrm{c} \pm 2.9$ & 72.0 & 88.0 & 3.6 \\
\hline & Sig. & & $* * *$ & & & \\
\hline & Total & 1054 & $76.3 \pm 3.6$ & 64.0 & 88.0 & 4.7 \\
\hline
\end{tabular}

Sig.= Significance; $* * *=\mathrm{P}<0.001 ; * *=\mathrm{P}<0.01 ; *=\mathrm{P}<0.05 ; \mathrm{NS}=$ not significant; $\mathrm{a} \neq \mathrm{b} \neq \mathrm{c}$ to $\mathrm{P} \leq 0.001$. 
Table II. Descriptive statistics of biometric lengths according to the parity class.

\begin{tabular}{|c|c|c|c|c|c|c|}
\hline Measure & Parity & $\mathbf{n}$ & Mean+SD & Minimum & Maximum & CV (\%) \\
\hline \multirow{5}{*}{ LT } & $1 \mathrm{~s}^{\mathrm{t}}$ & 403 & $166,9 \mathrm{a} \pm 8.2$ & 142.0 & 197.0 & 4.9 \\
\hline & 2nd and 3rd & 460 & $173.2^{\mathrm{b}} \pm 7.4$ & 151.0 & 195.0 & 4.3 \\
\hline & $\geq 4^{\text {th }}$ & 191 & $173.5^{\mathrm{b}} \pm 7.3$ & 148.0 & 191.0 & 4.2 \\
\hline & Sig. & & $* * *$ & & & \\
\hline & Total & 1054 & $170,8 \pm 8.3$ & 142.0 & 197.0 & 4.9 \\
\hline \multirow{5}{*}{ LR } & $1 \mathrm{~s}^{\mathrm{t}}$ & 403 & $52.9^{a} \pm 2.7$ & 43.0 & 61.0 & 5.1 \\
\hline & 2 nd and 3rd & 460 & $55.1^{\mathrm{b} \pm} 2.5$ & 48.0 & 64.0 & 4.5 \\
\hline & $\geq 4^{\text {th }}$ & 191 & $55.2^{\mathrm{b}}{ }^{ \pm} 2.8$ & 43.0 & 65.0 & 5.0 \\
\hline & Sig. & & $* * *$ & & & \\
\hline & Total & 1054 & $54,3 \pm 2.8$ & 43.0 & 65.0 & 5.2 \\
\hline \multirow{5}{*}{ LH } & $1 s^{t}$ & 403 & $51,1^{\mathrm{a} \pm}-2.0$ & 46.0 & 58.0 & 3.9 \\
\hline & 2nd and 3rd & 460 & $52.4^{\mathrm{b} \pm} 2.0$ & 47.0 & 59.0 & 3.8 \\
\hline & $\geq 4^{\text {th }}$ & 191 & $52.3^{\mathrm{b}} \pm 2.0$ & 47.0 & 57.0 & 3.8 \\
\hline & Sig. & & $* * *$ & & & \\
\hline & Total & 1054 & $51.9 \pm 2.1$ & 46.0 & 59.0 & 4.0 \\
\hline
\end{tabular}

Sig.= Significance; $* * *=\mathrm{P}<0.001 ; * *=\mathrm{P}<0.01 ; *=\mathrm{P}<0.05 ; \mathrm{NS}=$ not significant; $\mathrm{a} \neq \mathrm{b}$ to $\mathrm{P} \leq 0.001$.

Table III. Descriptive statistics of biometric widths according to the parity class

\begin{tabular}{|c|c|c|c|c|c|c|}
\hline Measure & Parity & n & Mean \pm SD & Minimum & Maximum & $\mathrm{CV}(\%)$ \\
\hline \multirow{5}{*}{ WH } & $1^{\mathrm{st}}$ & 403 & $21.1 \mathrm{a} \pm 1.3$ & 17.0 & 25.0 & 5.9 \\
\hline & $2^{\text {nd }} a_{\text {nd }} 3$ rd & 460 & $21.5 \mathrm{~b} \pm 1.2$ & 18.0 & 25.0 & 5.4 \\
\hline & $\geq 4_{\text {th }}$ & 191 & $21.6 \mathrm{~b} \pm 1.2$ & 18.0 & 25.0 & 5.6 \\
\hline & Sig. & & $* * *$ & & & \\
\hline & Total & 1054 & $21.3 \pm 1.2$ & 17.0 & 25.0 & 5.7 \\
\hline \multirow{5}{*}{ WC } & $1^{\text {st }}$ & 403 & $47,1 \mathrm{a} \pm 4.3$ & 36.0 & 70.5 & 9.1 \\
\hline & $2^{\text {nd }} a_{\text {nd }} 3$ rd & 460 & $49.0 \mathrm{~b} \pm 4.5$ & 36.0 & 74.0 & 9.1 \\
\hline & $\geq 4^{\text {th }}$ & 191 & $49.3 \mathrm{~b} \pm 4.9$ & 40.0 & 77.0 & 10.0 \\
\hline & Sig. & & $* * *$ & & & \\
\hline & Total & 1054 & $48.3 \pm 4.6$ & 36.0 & 77.0 & 9.5 \\
\hline \multirow{5}{*}{ WBIIL } & $1^{\mathrm{st}}$ & 403 & $53.0 \mathrm{a} \pm 3.65$ & 41.0 & 66.0 & 6.7 \\
\hline & $2^{\text {nd }} a_{\text {nd }} 3 \mathrm{rd}$ & 460 & $57.5 \mathrm{~b} \pm 3.4$ & 44.0 & 73.0 & 6.0 \\
\hline & $\geq 4_{\text {th }}$ & 191 & $58.3 \mathrm{c} \pm 3.4$ & 49.0 & 67.0 & 5.8 \\
\hline & Sig. & & $* * *$ & & & \\
\hline & Total & 1054 & $55,9 \pm 4.2$ & 41.0 & 73.0 & 7.5 \\
\hline \multirow{5}{*}{ WBIIS } & $1^{\text {st }}$ & 403 & $24,4 \mathrm{a} \pm 2.4$ & 17.0 & 33.0 & 10.0 \\
\hline & $2^{\text {nd }} a_{\text {nd }} 3$ rd & 460 & $26.0 \mathrm{~b} \pm 2.4$ & 19.0 & 34.0 & 9.1 \\
\hline & $\geq 4_{\text {th }}$ & 191 & $26.3 \mathrm{~b} \pm 2.5$ & 19.0 & 34.0 & 9.3 \\
\hline & Sig. & & $* * *$ & & & \\
\hline & Total & 1054 & $25.4 \pm 2.5$ & 17.0 & 34.0 & 10.0 \\
\hline
\end{tabular}

Sig.= Significance; $* * *=\mathrm{P}<0.001 ; * *=\mathrm{P}<0.01 ; *=\mathrm{P}<0.05 ; \mathrm{NS}=$ not significant; $\mathrm{a} \neq \mathrm{b} \neq \mathrm{c}$ to $\mathrm{P} \leq 0.001$. 
excess of the third class of lactation. In HC there were significant differences $(\mathrm{P}<0.001)$ between the three classes of lactation, with an increasing trend from first to fourth or greater lactation. The coefficients of variation were low, ranging between $3.1 \%$ in $\mathrm{HR}$ and $4.6 \%$ in $\mathrm{HC}$.

The length of trunk may be a reference measurement in the design of stable cows, in particular in the design of cubicles, had a mean value of $170.8 \pm 8.3 \mathrm{~cm}$, alternating between 142 and $197 \mathrm{~cm}$ (Table II). In lengths studied, it was found that first animal parity showed lower values for all parameters in analysis with significant differences $(\mathrm{P}<0.001)$, in relation to other classes.

Widths of head, chest and biischiatic found the existence of significant differences $(\mathrm{P}<0.001)$ between the first lactation and the other classes and in the case of $\mathrm{WC}$ and WBIIS with coefficients of variation in the order of $10 \%$. In width of biiliac were observed significant differences $(\mathrm{P}<0.001)$ among all classes of lactation studied, with priority for older animals (Table III). The results also pointed to greater morphological diversity in measurements of the width of chest and biischiatic with CV higher compared to other measurements, $9.5 \%$ and $10 \%$ respectively.

The cows of first lactation had an average value of the perimeter of the shin significantly lower $(\mathrm{P}<0.001)$ to the other classes of lactation (Table IV). In girth found significant differences $(\mathrm{P}<0.001)$ among all classes of lactation and there was an increase from first to fourth or greater lactation of about $13 \mathrm{~cm}$, indicating that this region develops until at least the fourth lactation. This is evident as a result of the high depth of the chest.

In general it was found an increase of height measurements associated with the development of animals according to the class of parity.

Different cubicles sizing are presented in Table V. In head to head cubicles measures of length, width and height were $223.0 \pm 11.0 \mathrm{~cm}, 113.0 \pm 5.0 \mathrm{~cm}$ and $110.0 \pm 7.0 \mathrm{~cm}$ respectively. While in cubicles against wall we obtained the dimensions of $227.0 \pm 18.0 \mathrm{~cm}, 111.0 \pm 7.0 \mathrm{~cm}$ and $110.0 \pm 8.0$ $\mathrm{cm}$ for length, width and height respectively.

Table IV. Descriptive statistics of biometric perimeters according to the parity class.

\begin{tabular}{|c|c|c|c|c|c|c|}
\hline Measure & Parity & n & Mean \pm SD & Minimum & Maximum & CV (\%) \\
\hline \multirow{5}{*}{ PS } & $1^{\mathrm{st}}$ & 403 & $19.1^{\mathrm{a} \pm}-0.8$ & 17.0 & 22.0 & 4.1 \\
\hline & $2^{\text {nd }} a_{n d} 3^{\text {rd }}$ & 460 & $19.5^{\mathrm{b}} \pm 0.8$ & 17.5 & 22.0 & 4.0 \\
\hline & $\geq 4^{\text {th }}$ & 191 & $19.4^{\mathrm{b}} \pm 0.8$ & 17.5 & 21.5 & 4.1 \\
\hline & Sig. & & $* * *$ & & & \\
\hline & Total & 1054 & $19.3 \pm 0.8$ & 17.0 & 22.0 & 4.1 \\
\hline \multirow{5}{*}{ PT } & $1^{\mathrm{st}}$ & 403 & $200.6 \mathrm{a} \pm 9.8$ & 173.0 & 231.0 & 4.9 \\
\hline & $2^{\text {nd }} a_{n d} 3^{\text {rd }}$ & 460 & $209.7 \mathrm{~b} \pm 8.8$ & 186.0 & 235.0 & 4.2 \\
\hline & $\geq 4^{\text {th }}$ & 191 & $213.0 \mathrm{c} \pm 8.5$ & 193.0 & 238.0 & 4.0 \\
\hline & Sig. & & $* * *$ & & & \\
\hline & Total & 1054 & $206.8 \pm 10.4$ & 173.0 & 238.0 & 5.0 \\
\hline
\end{tabular}

Sig. $=$ Significance; $* * *=\mathrm{P}<0.001 ; * *=\mathrm{P}<0.01 ; *=\mathrm{P}<0.05 ; \mathrm{NS}=$ not significant; $\mathrm{a} \neq \mathrm{b} \neq \mathrm{c}$ to $\mathrm{P} \leq 0.001$.

Table V. Measurements of the cubicles elements $(\mathrm{cm})$.

\begin{tabular}{llccccc}
\hline Cubicle type & Dimensions & Farms & Mean \pm SD & Minimum & Maximum & CV (\%) \\
\hline \multirow{5}{*}{ Head to head cubicle } & Cubicle back edge & 76 & $22.0 \pm 4.0$ & 12.0 & 35.0 & 19.04 \\
& Cubicle length & 60 & $223.0 \pm 11.0$ & 195.0 & 255.0 & 5.12 \\
& Cubicle width & 60 & $113.0 \pm 5.0$ & 104.0 & 121.0 & 4.05 \\
& Cubicle eight & 60 & $110.0 \pm 7.0$ & 94.0 & 128.0 & 6.72 \\
& Cubicle length & 50 & $227.0 \pm 18.0$ & 193.0 & 265.0 & 7.81 \\
Cubicle against wall & Cubicle width & 50 & $111.0 \pm 7.0$ & 98.0 & 130.0 & 6.43 \\
& Cubicle eight & 50 & $110.0 \pm 8.0$ & 92.0 & 130.0 & 7.52
\end{tabular}


Phenotypic correlations calculated, presented in Table VI, were all significant $(\mathrm{P}<0.001)$, except for some dimensions of length and width of the cubicles. Most of correlations were low with $71 \%$ of these coefficients below 0.50 . Only $5.5 \%$ were high $(\mathrm{R} \geq 0.70)$ as it follows in rank order: the HW and HB (0.87), between the HB and HR (0.84), between the HC and PT (0.80) between the HW and HR (0.74) and between HR and HPB (0.75). The correlations between the different measurements with the highest value highlight the relationship between height and girth. It will highlight the close relationship between the heights at the withers, mid back, rump and at pin bones. In the analysis of correlations calculated between the different variables were observed on very weak and some non-significant $(\mathrm{P}>0.05)$ between body measurements and dimensions of the cubicles. We found that the correlation between the length of the cubicle and the length of trunk as well as non-significant was extremely low (0.03) and the correlation between the width of the cubicle and the width of chest (0.05) width of biiliac that, although significant $(\mathrm{P}<0.01)$ also had very low value $(0.09)$.

Table VI. Phenotypic correlations between the different biometric measures and cubicle dimensions

\begin{tabular}{|c|c|c|c|c|c|c|c|c|c|c|c|c|c|c|c|}
\hline Measures & HB & HR & HPB & $\mathrm{HC}$ & LT & LR & LH & WH & WC & WBIIL & WBIIS & PS & PT & CL & $\mathrm{CW}$ \\
\hline HW & 0.87 & 0.74 & 0.60 & 0.67 & 0.48 & 0.55 & 0.41 & 0.16 & 0.22 & 0.52 & 0.36 & 0.42 & 0.58 & 0.08 & 0.09 \\
\hline HB & & 0.84 & 0.60 & 0.60 & 0.43 & 0.52 & 0.37 & 0.14 & 0.21 & 0.44 & 0.32 & 0.37 & 0.52 & 0.06 & 0.08 \\
\hline HR & & & 0.75 & 0.49 & 0.43 & 0.48 & 0.31 & 0.09 & 0.15 & 0.36 & 0.32 & 0.39 & 0.40 & 0.11 & 0.10 \\
\hline НPB & & & & 0.38 & 0.42 & 0.37 & 0.29 & 0.08 & 0.09 & 0.32 & 0.27 & 0.33 & 0.29 & 0.16 & 0.12 \\
\hline $\mathrm{HC}$ & & & & & 0.55 & 0.54 & 0.40 & 0.22 & 0.35 & 0.57 & 0.39 & 0.45 & 0.80 & $0.01 *$ & $0.07 *$ \\
\hline $\mathrm{LT}$ & & & & & & 0.60 & 0.42 & 0.33 & 0.18 & 0.54 & 0.29 & 0.35 & 0.49 & $0.03 *$ & $0.07 *$ \\
\hline LR & & & & & & & 0.45 & 0.32 & 0.34 & 0.55 & 0.32 & 0.35 & 0.58 & $0.05 *$ & $-0,02 *$ \\
\hline LH & & & & & & & & 0.43 & 0.16 & 0.40 & 0.25 & 0.26 & 0.38 & $-0,01^{*}$ & -0.06 \\
\hline WH & & & & & & & & & 0.19 & 0.21 & 0.18 & 0.23 & 0.32 & -0.01 & -0.12 \\
\hline WC & & & & & & & & & & 0.24 & 0.22 & 0.24 & 0.63 & -0.07 & -0.05 \\
\hline WBIIL & & & & & & & & & & & 0.46 & 0.38 & 0.58 & 0.07 & 0.09 \\
\hline WBIIS & & & & & & & & & & & & 0.31 & 0.42 & $-0,01 *$ & 0.15 \\
\hline PS & & & & & & & & & & & & & 0.46 & $0.04 *$ & $0.05^{*}$ \\
\hline CL & & & & & & & & & & & & & & & $0.38 *$ \\
\hline
\end{tabular}

* Not significant.

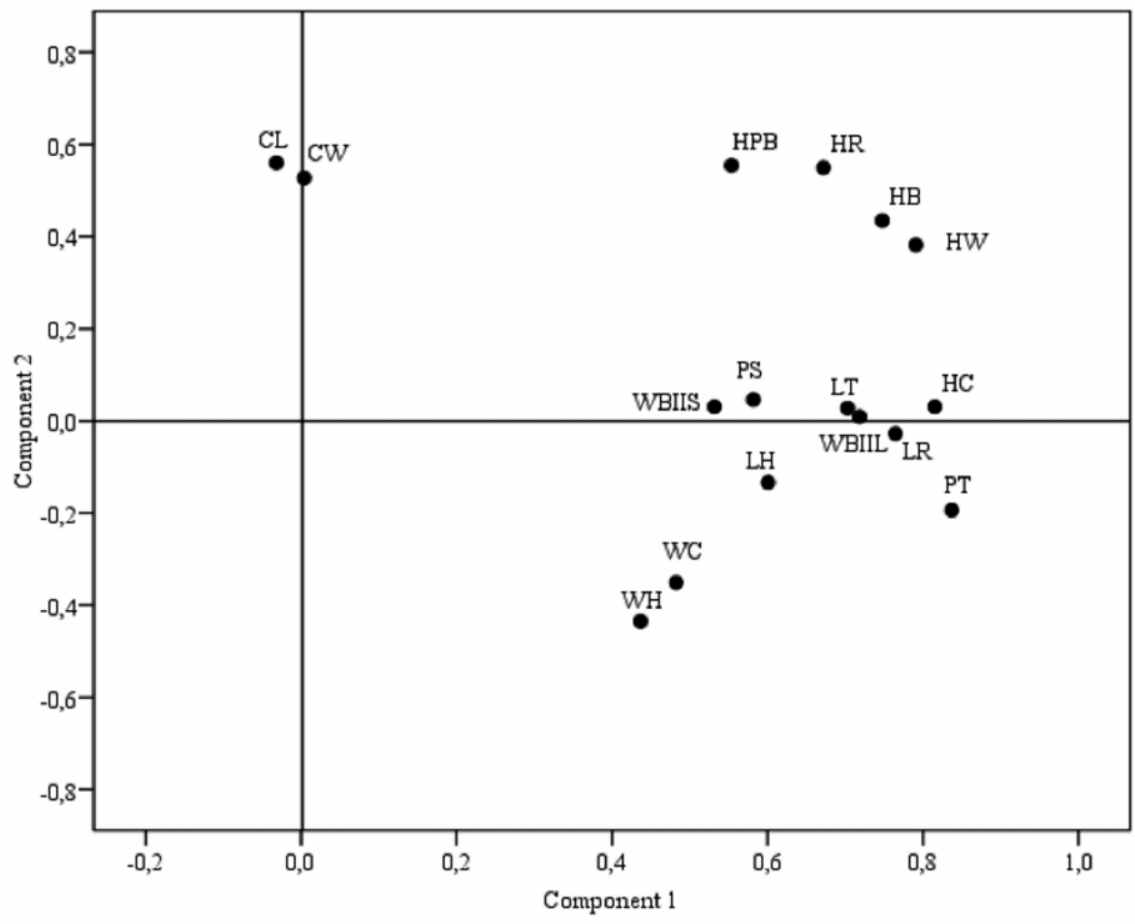

Fig. 2. Projection of the original variables on the axes defined by the first two principal components 
Table VII. Result of principal component analysis of the different body measurements ( $\mathrm{n}=992)$.

\begin{tabular}{lccc}
\hline Characters & Component 1 & Component 2 & Communalities \\
\hline HW & $0.791^{*}$ & 0.382 & 0.771 \\
HB & $0.748^{*}$ & 0.435 & 0.748 \\
HR & $0.672^{*}$ & $0.549^{*}$ & 0.753 \\
HPB & $0.554^{*}$ & $0.555^{*}$ & 0.614 \\
HC & $0.815^{*}$ & 0.031 & 0.666 \\
LT & $0.703^{*}$ & 0.028 & 0.495 \\
LR & $0.765^{*}$ & -0.028 & 0.585 \\
LH & $0.601^{*}$ & -0.134 & 0.379 \\
WH & 0.437 & -0.435 & 0.380 \\
WC & 0.482 & -0.351 & 0.356 \\
WBIIL & $0.718^{*}$ & 0.009 & 0.516 \\
WBIIS & $0.532^{*}$ & 0.031 & 0.283 \\
PS & $0.582^{*}$ & 0.046 & 0.341 \\
PT & $0.837^{*}$ & -0.194 & 0.738 \\
CL & -0.032 & $0.560^{*}$ & 0.315 \\
CW & 0.004 & $0.527 *$ & 0.278 \\
Own values & 6.44 & 1.78 & --- \\
\% Explained variance & 40.22 & 11.13 & -- \\
$\%$ Cumulative variance & 40.22 & 51.35 & --- \\
\hline
\end{tabular}

* Values greater than 0.50 .

Results of principal component analysis of the different body measurements and cubicles dimensions are presented in Table VII. When considering the two components as a whole express $51.4 \%$ of the total variability. The first factor represented $40.2 \%$ of the variability, and one negative coefficient (CL). The variables most correlated with this factor were the heights at the withers, mid back, rump and chest, length of trunk and rump, width of biiliac and perimeter of the thorax. The second factor represented $11.1 \%$ of the total variability, being the most important measures the heights at rump and pin bones, cubicle length and width. It was possible to verify that the measures of heights and perimeter of the thorax had a great relationship (high communalities) with the components analyzed.

In the projection of the variables in the plane defined by the first two principal components (Fig. 2), there was one negative value (CL), together $\mathrm{CW}$ in the second main component. All the measures of height can be distinguished on the first principal component away from the origin, except height at chest. Another group of the width of the head and chest was away from the origin and the first principal component.

\section{DISCUSSION}

In the present study, height measurements obtained were all higher than those referenced by various authors (Batra \& Touchberry, 1974; Ali et al., 1984; Yerex et al., 1988; Sieber et al., 1988; Enevoldsen \& Kristensen).

The height at the rump is an extremely important measure, because it is easily measured and because many body measurements will be proportional, and according to Anderson (2008) serves as useful reference point for the design of the cubicles.

It should be noted that the values obtained in HolsteinFriesian were slightly higher than those presented in height at withers and rump, and much higher height at pin bones, referred to Ali et al. Values lower and significantly different that were found in the third class of parity for the first two to the height at pin bones in the order of $2 \mathrm{~cm}$, possibly be related to the tendency to curl the rump, with significant sag of the hindquarters cows in function of age. This evidence may also be associated with problems of lameness, usually in which 
animals have arched back. The difference between the height at rump and at pin bones by us obtained is half $(5 \mathrm{~cm})$ from the referenced by Ali et al., $(10 \mathrm{~cm})$, which shows a trend towards lower slope of the rump in contemporary animals.

The length of trunk $(170.8 \pm 8.3 \mathrm{~cm})$ was higher than referenced by Batra \& Touchberry and Sieber et al., at approximately 14 to $16 \mathrm{~cm}$. Although the distance between the nose and tail of the animal to be critical, it is a very difficult to collect as the animal, so the length of the body is of crucial importance in the design of stable, across the width of the passing lanes, but mainly in the design and dimensioning of the cubicles length. For length of rump values ranged from $52.8 \mathrm{~cm}$ in younger animals and $55.2 \mathrm{~cm}$ in the animals of the third class of parity, slightly higher than those observed (53.7 $\mathrm{cm})$ by Sieber $e t$ al. The head is characterized by being long and dolicocephaly, wherein the head has an oval shape, the diameter is one fourth of the longitudinal direction. Length measurements observed by us are giving scientific credibility to the status of Holstein-Friesian, when considered as an animal characteristically elongated.

For the width of biiliac there was an increase of $2 \mathrm{~cm}$ on the values given by Sieber et al., however Enevoldsen \& Kristensen found identical values.

In turn, Ali et al., mentioned that the rump characteristic are influenced on the animals longevity due to its relationship with the calving difficulty, that cows with greater width at rump and with intermediate rump angle (inclined rumps) have fewer problems associated with the calving difficulty. The width of biischiatic also suffered an increase of approximately $5 \mathrm{~cm}$ in relation to that observed by Ali et al., for this breed.

The perimeter of the thorax had become quite large in view of the high chest depth with a positive difference of 4 $\mathrm{cm}$ and $12 \mathrm{~cm}$, to in connection with those reported by Ali et al., and Sieber et al. Differences were found for this measure among all classes of parities, an increase of $9 \mathrm{~cm}$ and $3 \mathrm{~cm}$ from first to second and third grade for this parity respectively, indicating that the animals remain growing until at least the fourth lactation.

The relatively low correlations between the different heights and perimeter of the thorax can translate a little proportional development of the animal's body. The indicator that may contradict this statement was at chest level, noting that the correlation coefficient is quite high, between the depth of the chest and perimeter of the thorax. But the correlations, although significant are low between measures of height, girth and length of rump, this reinforces the idea of a little harmonious development between the different constituent parts of the cow.
The communalities observed in height at rump and perimeter of the thorax indicated a strong relationship with the first two principal components, extremely important that the reliability and representativeness of biometric studies, based on these two measures using the tapes.

The weak correlations observed between the measurements and dimensions of the animal cubicles lead us to affirm that the cubicles are constructed in a standardized manner, without taking into account the morphological characteristics of animals in each herd. Given the obtained results it appears that there is no adequacy between the design of the cubicles and the body size of the animals. This factor may have a negative influence on the quality of their rest, especially in cows with greater body size.

\section{CONCLUSIONS}

In the present study the Holstein-Friesian cows showed differences between the first class of parity and the others for most of the measures, which is associated with its physical development. Revealed an increase in all body measurements, especially at the level of the rump, which also showed a less inclination, justifying the tendency to select breeding animals with a posterior third too high and wide. Correlations between body measurements of dairy cows and the dimensions of the cubicles were low which shows that there is no adjustment between the corpulence of the animals and their facilities, which adversely affects their welfare.

ACKNOWLEDGEMENTS. All farmers participating in the study are gratefully acknowledged for cooperation. This work was supported by the Foundation for Science and Technology (FCT-Portugal) and Instituto Politécnico de Viana do Castelo.

CERQUEIRA, J. O. L.; ARAÚJO, J. P. P.; VAZ, P. S.; CANTALAPIEDRA, J.; BLANCO-PENEDO, I. \& NIZARIBEIRO, J. J. R. Relación entre medidas zoométricas en vacas Holstein-Friesian y dimensiones de cubículos en granjas lecheras. Int. J. Morphol., 31(1):55-63, 2013.

RESUMEN: Fueron investigadas las medidas corporales en la raza Holstein-Friesian Portuguesa y su asociación con las dimensiones de los cubículos. Durante un período de 5 meses, se recogieron las medidas corporales y los datos de tamaño de cubículos de 55 explotaciones lecheras comerciales portuguesas incluyendo un total de 1054 animales. Los datos fueron analizados utilizando el modelo linear general y componentes principa- 
les. Las medidas del cuerpo más relevantes fueron: altura a la cruz $(141,1 \pm 4,7 \mathrm{~cm})$, altura a la grupa $(144,2 \pm 4,5 \mathrm{~cm})$, longitud del tronco $(170,8 \pm 8,3 \mathrm{~cm})$, ancho biisquiática $(55,9 \pm 4,2 \mathrm{~cm})$ y el perímetro del tórax $(206,8 \pm 10,4 \mathrm{~cm})$. En general, la primera paridad reveló diferencias $(\mathrm{P}<0,001)$, lo que se encuentra asociado con el desarrollo de los animales. La longitud y la ancho del cubículo cabeza con cabeza fue $223 \pm 11 \mathrm{~cm}$ y $113 \pm 5 \mathrm{~cm}$ respectivamente, mientras que en el cubículo frente a la pared, la longitud fue $227 \pm 18 \mathrm{~cm}$ y el ancho de $111 \pm 7 \mathrm{~cm}$. Las medidas del cuerpo con las más altas correlaciones se observaron entre las diferentes alturas y entre la altura del pecho y el perímetro del tórax. El análisis no evidenció relación alguna entre las medidas del cuerpo y las dimensiones de los cubículos. El análisis de componentes principales de las medidas del cuerpo y de las diferentes dimensiones de los cubículos explican el 51,4\% de la variabilidad total, en la que el primer factor representa el $40,2 \%$ y el segundo el $11,1 \%$.

Cubículos.

PALABRAS CLAVE: Holstein-Friesian; Medidas;

\section{REFERENCES}

Agnew, R. E.; Yan, T.; Murphy, J. J.; Ferris, C. P. \& Gordon, F. J. Development of maintenance energy requirement and energetic efficiency for lactation from production data of dairy cows. Livest. Prod. Sci., 82(2-3):151-62, 2003.

Ali, T. E.; Burnside, E. B. \& Schaeffer, L. R. Relationship between external body measurements and calving difficulties in Canadian Holstein-Friesian cattle. J. Dairy Sci., 67(12):303444, 1984.

Anderson, N. Tie stall dimensions for dairy cows. Ontario, Ministry of Agriculture, Food and Rural Affairs, 2008.

Araújo, J. P.; Cerqueira, J. L.; Alonso, J. M.; Mamede, J.; Niza Ribeiro, J. \& Cantalapiedra, J. Algunos indicadores de los sistemas de producción de leche en la región de Entre Douro e Minho. Madrid, I Congreso Nacional de Zootecnia, 2007. p. 120 .

Batra, T. R. \& Touchberry, R. W. Weights and Body Measurements of Purebred Holstein and Guernsey Females and Their Crossbreds. J. Dairy Sci., 57(7):842-8, 1974.

Camargo, O. The dairy cow: between economic efficiency and biological inefficiency. Arch. Zootec., 61:13-29, 2012.

EFSA. Panel on Animal Health and Welfare (AHAW). Scientific Opinion on the use of animal-based measures to assess welfare of dairy cows. EFSA Journal, 10(1):2554, 2012.

Enevoldsen, C. \& Kristensen, T. Estimation of body weight from body size measurements and body condition scores in dairy cows. J. Dairy Sci., 80(9):1988-95, 1997.
FENALAC. Evolução estrutural recente da produção de leite em Portugal. Campus lácteo, 6:20-2, 2011.

Knaus, W. Dairy cows trapped between performance demands and adaptability. J. Sci. Food Agr., 89(7):1107-14, 2009.

Linnane, M.; Horan, B.; Connolly, J.; O'connor, P.; Buckley, F. \& Dillon, P. The effect of strain of Holstein-Friesian and feeding system on grazing behaviour, herbage intake and productivity in the first lactation. Anim. Sci., 78(1):169-78, 2004.

Overton, M. W.; Sischo, W. M.; Temple, G. D. \& Moore, D. A. Using time-lapse video photography to assess dairy cattle lying behaviour in a free-stall barn. J. Dairy Sci., 85(9):2407-13, 2002 .

Peters, R. H. The ecological implications of body size. New York, Cambridge University Press, 1993. p.329.

Petherick, J. C. Spatial requirements of animals: Allometry and beyond. J. Vet. Behav. Clin. Appl. Res., 2(6):197-204, 2007.

Petherick, J. C. \& Phillips, C. J. C. Space allowances for confined livestock and their determination from allometric principles. Appl. Anim. Behav. Sci., 117(1):1-12, 2009.

Sieber, M.; Freeman, A. E. \& Kelley, D. H. Relationships between Body Measurements, Body Weight, and Productivity in Holstein Dairy Cows. J. Dairy Sci., 71(12):3437-45, 1988.

Yerex, R. P.; Young, C. W.; Donker, J. D. \& Marx, G. D. Effects of Selection for Body Size on Feed Efficiency and Size of Holsteins. J. Dairy Sci.,, 71(5):1355-60, 1988.

Correspondence to:

Joaquim Orlando Lima Cerqueira

Escola Superior Agrária de Ponte de Lima

Mosteiro - Refóios do Lima

4990-706 Ponte de Lima

PORTUGAL

Email: cerqueira@esa.ipvc.pt

Received: 27-06-2012

Accepted: 10-08-2012 